\title{
Vegetation structure and composition in Ciletuh Geopark, Sukabumi, Indonesia
}

\author{
INDRI WULANDARI ${ }^{1,3, \boldsymbol{v}}$, RANDI HENDRAWAN ${ }^{1,3}$, TEGUH HUSODO ${ }^{1,2,3}$, ERRI N. MEGANTARA $^{1,2,3}$ \\ ${ }^{1}$ Department of Biology, Faculty of Mathematics and Natural Sciences, Universitas Padjadjaran. Jl. Raya Bandung-Sumedang Km 21, Jatinangor, \\ Sumedang 45363, West Java, Indonesia. Tel.: +62-22-7797712, `email: indri.wulandari@unpad.ac.id. \\ ${ }^{2}$ Program in Environmental Science, School of Graduates, Universitas Padjadjaran. Jl. Sekeloa, Coblong, Bandung 40134, West Java, Indonesia \\ ${ }^{3}$ Institute of Ecology, Directorate of Research, Community Services and Innovation, Universitas Padjadjaran. Jl. Sekeloa, Coblong, Bandung 40134, \\ West Java, Indonesia
}

Manuscript received: 2 July 2018. Revision accepted: 15 August 2018.

\begin{abstract}
Wulandari I, Hendrawan R, Husodo T, Megantara EN. 2018. Vegetation structure and composition in Ciletuh Geopark, Sukabumi, Indonesia. Asian J For 2: 54-61. Ciletuh Geopark has unique geological and biological features which might provide benefits both to the environment and society. The sustainable management of the geopark requires information on biodiversity elements including the vegetation occurring around Ciletuh Geopark. This research was conducted to determine vegetation communities and plants diversity of the Ciletuh Geopark. The method used was a qualitative method through inventory of plant species and observation of the vegetation profile diagram, which represents a vertical structure of the vegetation community. In general, Ciletuh Geopark had four types of communities, namely natural forests, gardens, agroforest (talun/kebon tatangkalan), and beach and mangrove vegetation. In total, there were 179 plant species recorded from understorey to trees including plant species protected by the Indonesian government, namely Rafflesia patma. In the geopark, there had been changes in vegetation which is now dominated by crop plant species. This study highlights the importance of conserving the remaining natural vegetation in Ciletuh Geopark to enhance the biological values of the geopark.
\end{abstract}

Keywords: Ciletuh, geopark, composition, structure, vegetation

\section{INTRODUCTION}

In the last 15 years, there is an emerging interest of global community in the establishment and development of geopark. This is a new initiative promoted by UNESCO that aims to conserve areas with high importance not only on geological interests but also regarding biological diversity. So far, larger attention is highlighted on the geological aspects while the biodiversity issues are rather overlooked.

Ciletuh Geopark is located in Sukabumi, West Java, Indonesia. It was established in September 2016 through the Decree of the Governor of West Java No. 556/Kep. 941-Rek/2016. Administratively, Ciletuh Geopark encompasses eight sub-districts, namely Cisolok, Cikakak, Palabuhanratu, Simpenan, Ciemas, Ciracap, Waluran, and Surade. One of the aims of the establishment of this geopark is among others to support sustainable development, especially in Sukabumi and West Java Province.

Particular aspect in Ciletuh Geopark that can be explored to be utilized sustainably is the biodiversity elements. However, since the establishment of Ciletuh Geopark, not many efforts were carried out to reveal information regarding plant and animal diversity in the area. Previous study by Megantara (2016) in Ciletuh Geopark only focused on an inventory of REEPS (Rare, Endangered, Endemic, Protected Species) of animals species. As such, studies need to be expanded to reveal information regarding plants or vegetation of Ciletuh Geopark.

Gem (1996) states that vegetation is a collection of species of plants, each of which is incorporated in a population that lives in habitat and interacts with one another. Interaction in a community is reflected in the structure and composition of vegetation. Stratification in a community occurs because of competition between dominant species with other species or between tall trees in the uppermost layers controlling the trees below (Soerianegara and Indrawan 2005). The interaction between plants gives rise to a characteristic composition of vegetation. MuellerDombois and Ellenberg (1974) use the term composition to express the floristic wealth of forests. Soerianegara and Indrawan (2005) add that species composition is distinguished between population (one species) and community (some species). The composition of vegetation is defined as the variation in the plant species that arrange community. The composition of plant species is a floristic list in a community (Misra 1973).

The purpose of this research is to find out plant diversity and vegetation community occurring in Ciletuh Geopark. The results of this study are expected to serve as baseline information for the management of the geopark as well as for future studies looking at the dynamics of the vegetation over a certain period. 


\section{MATERIALS AND METHODS}

\section{Study area}

This study was carried out in Ciletuh Geopark, Sukabumi, West Java, Indonesia. Data collection was concentrated in the horseshoe-shaped buffer area surrounding the Amphitheater (Figure 1). The Amphitheater has high importance since the government plans that this area would be projected as the center of Ciletuh's economic growth. In general, the Amphitheater is located in low elevation so that vegetation occurring in this area can be classified as lowland forest. A previous study by Megantara (2016) showed that the Amphitheater is the habitat animal species with REEPS status.

\section{Methods}

Data collection was carried out through an inventory of plant species as well as direct observation to capture the vegetation profiles. Stratification and vegetation profiles were drawn by profile diagram vertically (MuellerDombois and Ellenberg 1974). Profile diagram was aimed to understand the structure of vegetation and created based on transect with length of $200 \mathrm{~m}$ and plot with size of $10 \mathrm{x}$ $10 \mathrm{~m}^{2}$. The profile diagram represented vertical structure of vegetation at four types of communities, namely (i) natural forests (Selagedang Hulu, Curug Awang Bawah, Curug Tengah, Puncak Manik, Cipeucang Atas, Curug Dogdog,
Curug Cimarinjing), (ii) gardens (Kebun Jati Selagedang, Kebun Kelapa Tamanjaya, Curug Awang Atas), (iii) agroforests (Cigembong, Cipeucang Bawah, MandrajayaCiwaru, Pasir Muncang, Gunung Masigit), and (iv) coastal vegetation/mangroves (Mangrove Cikadal).

The profile diagram depiction was created on millimeter block paper with a scale of 1: 100. In the picture, it is added information such as research title, scale, species code, tree height scale, species name, and location map and study transect.

Data were analyzed using the qualitative-descriptive method to describe the condition of vegetation at the study location. Based on vegetation profile, the canopy strata were formed. The determination of the amount of strata is very dependent on the personal decision of the researcher.

\section{RESULTS AND DISCUSSION}

\section{Vegetation community type}

There were four vegetation community types found at the study sites in Ciletuh Geopark, namely natural forests, gardens, agroforest (talun/kebon tatangkalan), and beach and mangrove vegetation. Natural forest and agroforests dominated the landscape in Ciletuh Geopark. The description of each vegetation is as follows.

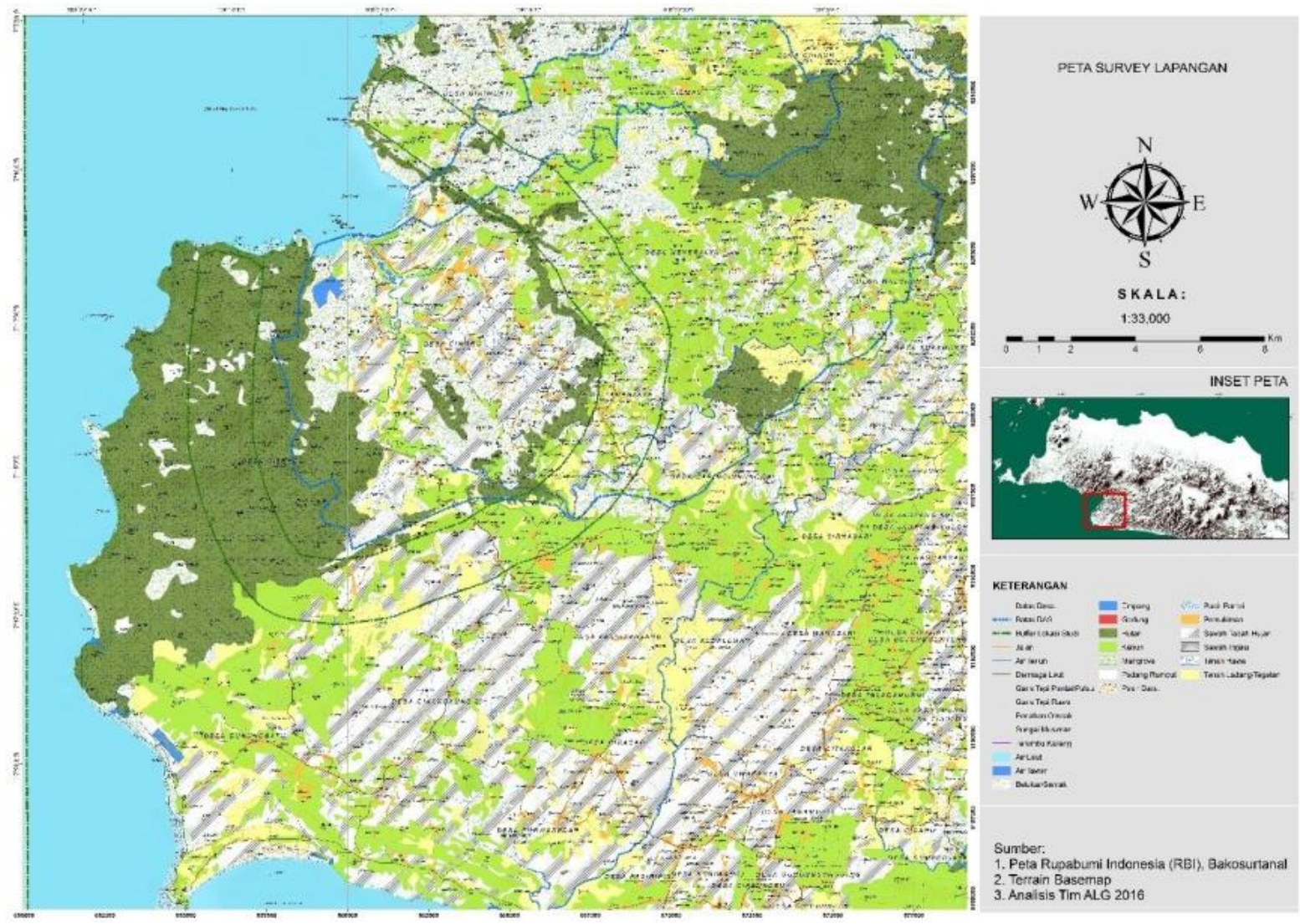

Figure 1. Map of the study location in Ciletuh Geopark, Sukabumi, West Java, Indonesia 


\section{Forests}

Forest was arranged by natural vegetation. The surrounding area of the forest had undergone land-use change into agricultural land. The forest was located on steep slopes which were difficult to reach, such as around waterfalls and cliffs, thus saving it from encroachment for land clearing. The forest around waterfall had a slope of $50-90 \%$, but the other forest around the Curug Dog-dog had slope between $20-30 \%$, which tends to be flat. Meanwhile, the forest around the cliff has slope between $40-80 \%$. In general, the canopy closure of forests around the cliff tended to be denser while the forest around waterfall was more open although in Curug Dog-dog it had a closed canopy closure (70-80\%).

\section{Garden}

In general, gardens dominated the landscape in Ciletuh Geoparks. It is arranged by agricultural land consisting of cultivated vegetation, such as horticultural crops. Some gardens were cultivated by single crops (monoculture) while other gardens were planted with various crops to form intercropping vegetation (polyculture). Plant species that were often found in the garden included teak, coconut, rice, corn, and bananas. However, there were species being the main commodities of each garden, such as teak and coconut, which were the main commodities. The gardens had a relatively flat and wavy topography, with a slope of $<50 \%$. The canopy closure of the garden was relatively open, so sunlight can penetrate the ground.

\section{Agroforest (Talun/kebon tatangkalan)}

In Ciletuh Geopark, agroforest was generally located in a relatively flat area. Canopy closure was not too dense, around $50 \%$. Talun which had slope of $>50 \%$ and a fairly close canopy closure can be found in Keusik Bodas area with slope of $50-70 \%$ and canopy cover of $75-95 \%$.

\section{Beach and mangrove vegetation}

Beach and mangrove vegetation communities were located in coastal areas, so plant communities had adapted to high salinity. This area had a broad coastal vegetation formation because most of the land haf been turned into cattle grazing and residential areas. Coastal and mangrove vegetation were separated by village and river roads with relatively flat topography.

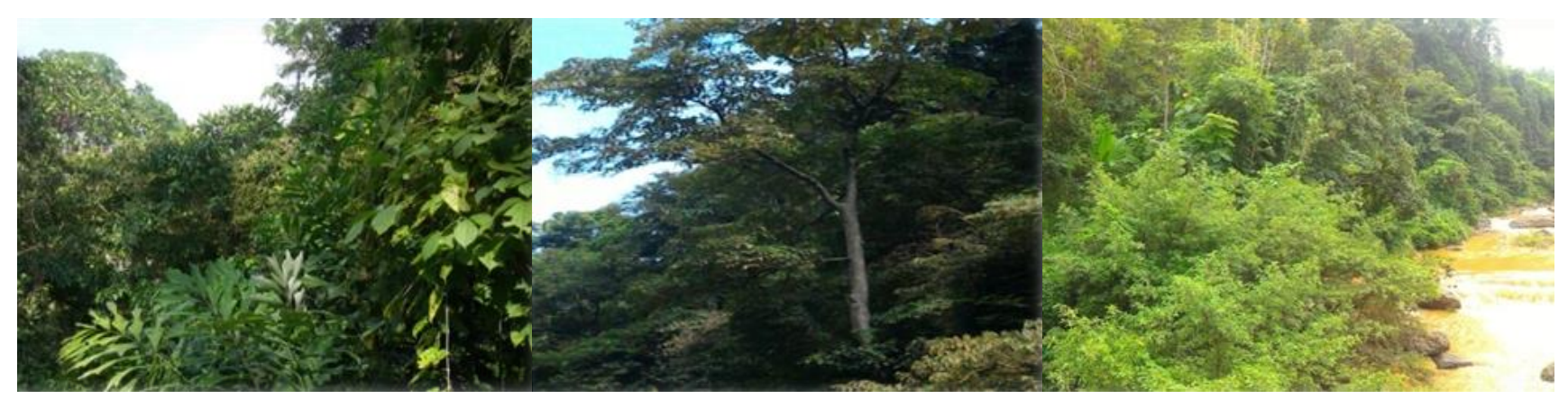

Figure 1. Vegetation communities of natural forest in Ciletuh Geopark, West Java, Indonesia

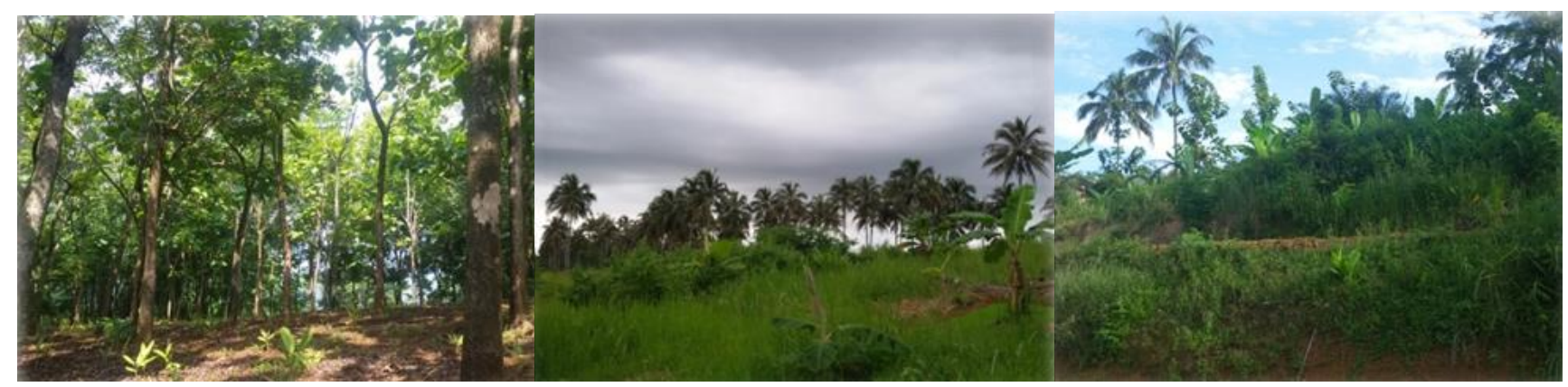

Figure 2. Vegetation communities of garden in Ciletuh Geopark, West Java, Indonesia

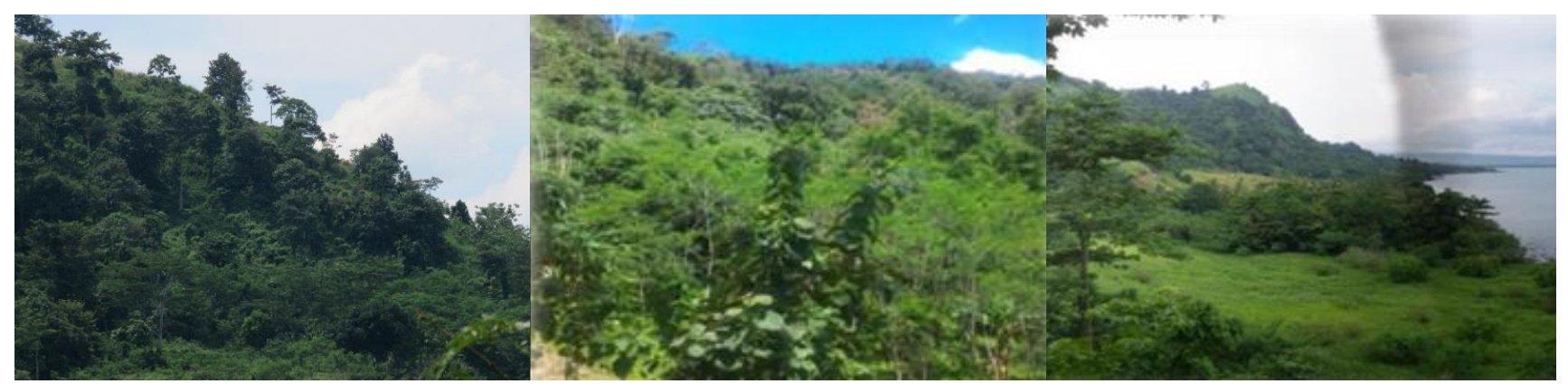

Figure 3. Vegetation communities of agroforest (talun/kebon tatangkalan) in Ciletuh Geopark, West Java, Indonesia 


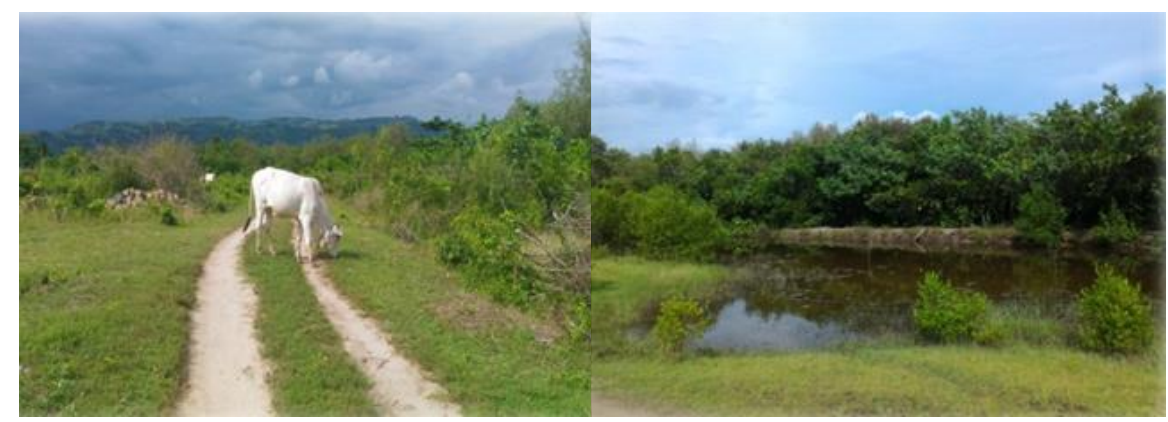

Figure 4. Vegetation communities of beach and mangrove in Ciletuh Geopark, West Java, Indonesia

\section{Structure of vegetation community}

Wyatt-Smith (1963) classify the structure of vegetation communities into four categories, namely trees, poles, saplings, and undergrowth. Tree is woody plants with diameter at breast height $(\mathrm{DBH})>35 \mathrm{~cm}$, pole is a woody plant with a diameter of 10-35 cm, sapling is a woody plant with a diameter of $<10 \mathrm{~cm}$ or has a height of $>1.5 \mathrm{~m}$ and undergrowth is vegetation with a height of $<1.5 \mathrm{~m}$. Soerianegara and Indrawan (2005) classify vegetation structure based on the level of layers from top to bottom horizontally, namely strata A, B, C, D, and E. Strata A is plants that have a height $>30 \mathrm{~m}$, strata $\mathrm{B}$ consists of plants with a height between $20-30 \mathrm{~m}$, strata $\mathrm{C}$ consists of plants with a height between 4-20 m, and strata $\mathrm{D}$ and $\mathrm{E}$ each are plants with a height $1-4 \mathrm{~m}$ and $<1 \mathrm{~m}$, respectively.

Generally, the vegetation in the Ciletuh Geopark had complex structures, starting from tree level to the sapling and also arranged by undergrowth vegetation. Based on its stratification, vegetation in the Ciletuh Geopark was dominated by strata B (height between 20-30 m) and C (height between 4-20 m).

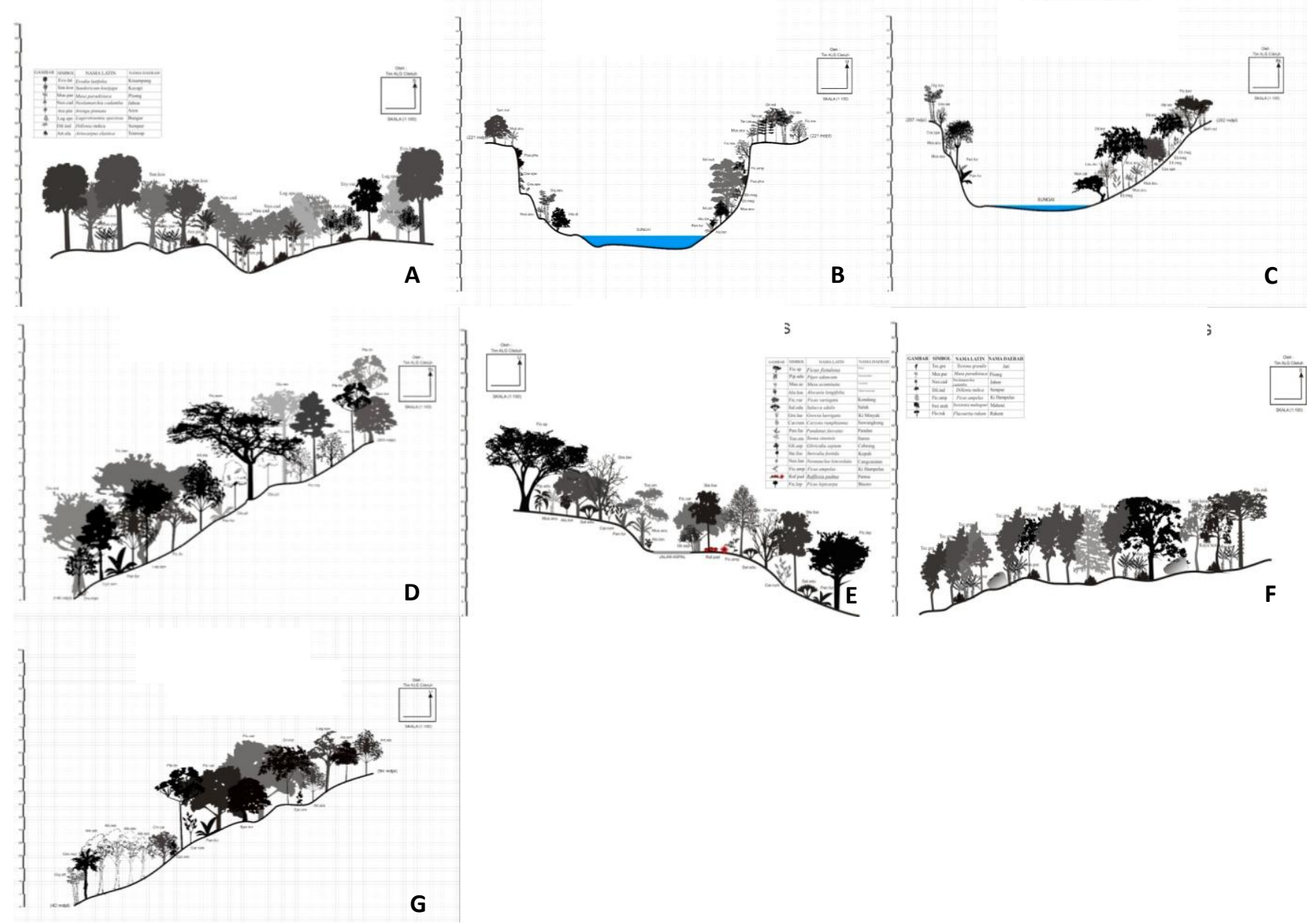

Figure 5. Vegetation profile diagram of natural forest in Ciletuh Geopark, West Java, Indonesia. A. Selagedang Hulu, B. Curug Awang Bawah, C. Curug Tengah, D. Puncak Manik, E. Cipeucang Atas, F. Curug Dogdog, G. Curug Cimarinjing 


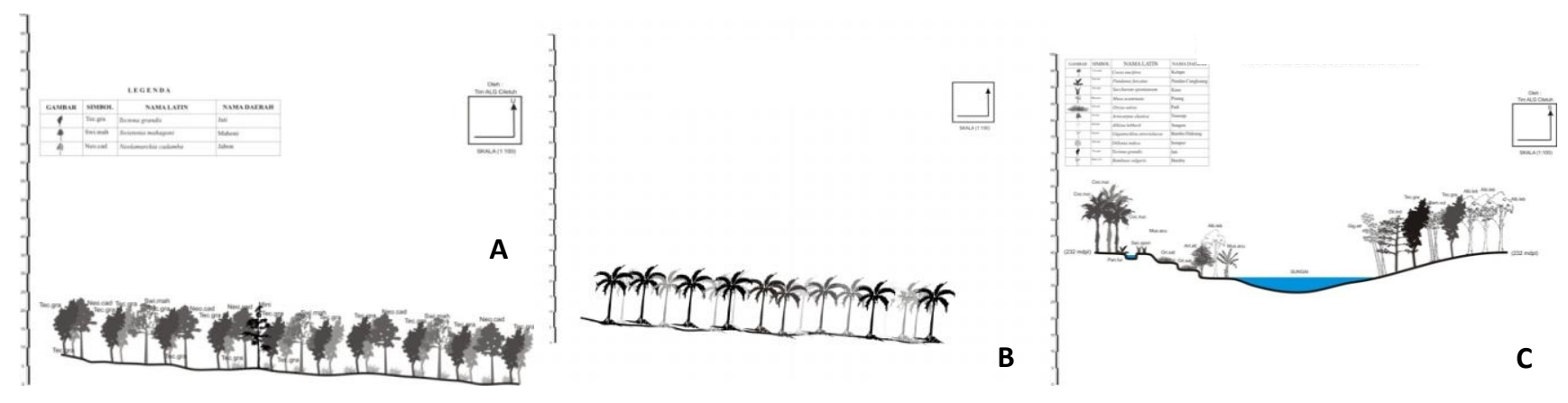

Figure 6. Vegetation profile diagram of garden in Ciletuh Geopark, West Java, Indonesia. A. Kebun Jati Selagedang, B. Kebun Kelapa Tamanjaya, C. Curug Awang Atas

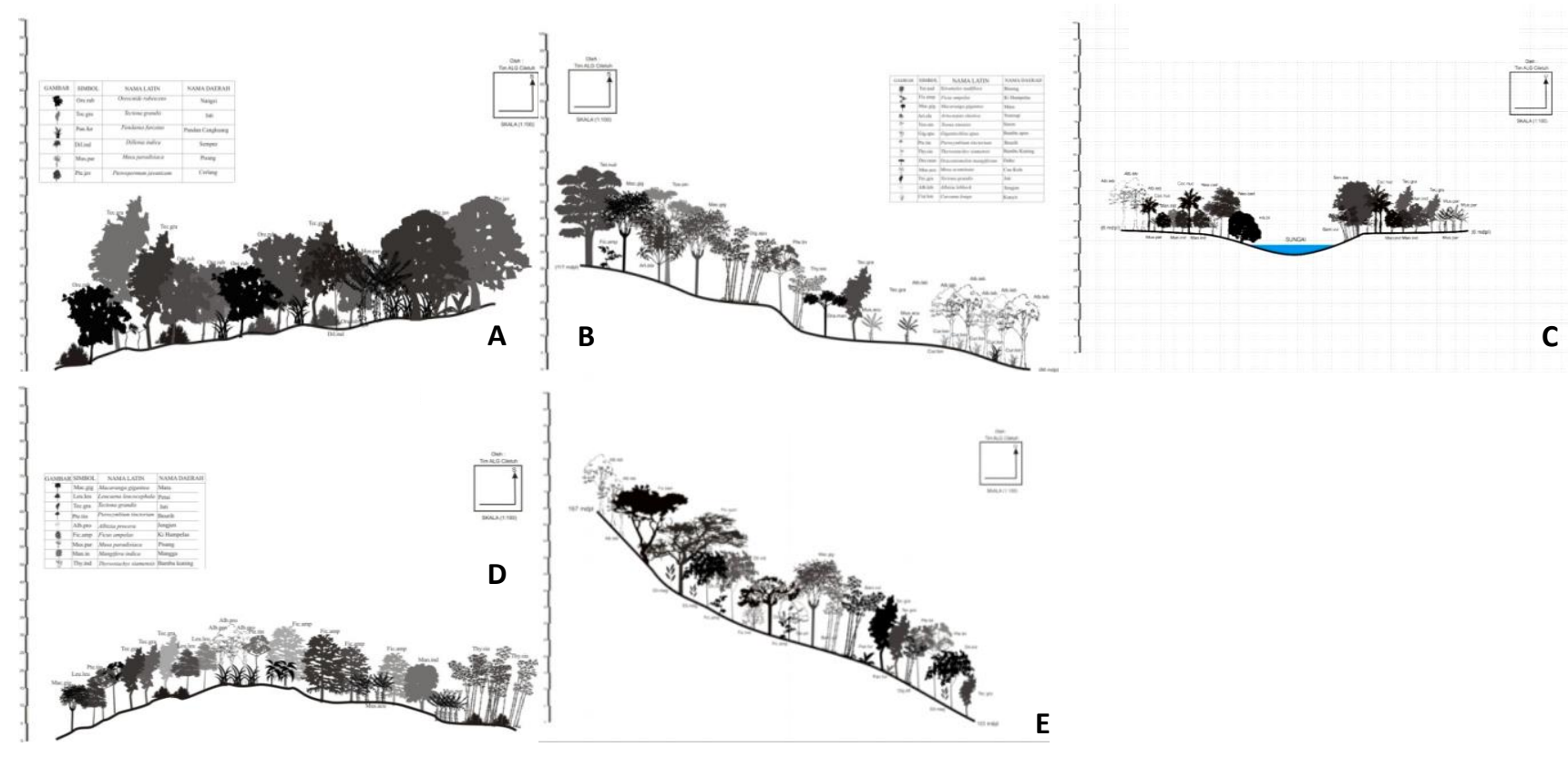

Figure 7. Vegetation profile diagram of agroforest (talun/kebon tatangkalan) in Ciletuh Geopark, West Java, Indonesia. A. Cigembong, B. Cipeucang Bawah, C. Mandrajaya-Ciwaru, D. Pasir Muncang, E. Gunung Masigit

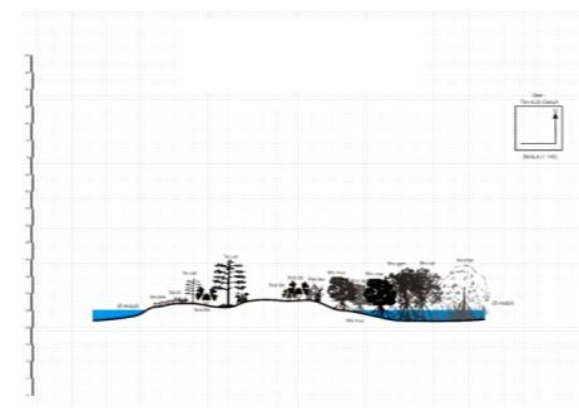

Figure 8. Vegetation profile diagram of mangrove in Ciletuh Geopark, West Java, Indonesia, i.e., Mangrove Cikadal. 


\section{Vegetation composition}

Vegetation inventory recorded 179 species across all types of vegetations. Family with the highest number of species were Fabaceae and Moraceae with 13 species. The forests in Ciletuh Geopark had high species diversity compared to garden and agroforest. The most dominant species were from family Moraceae, such as Ficus ampelas Burm.f. and Ficus rostrata Thunb.

In contrast to forest and agroforest, the vegetation of garden and coastal and mangrove was different. In the garden, there were various agricultural crops species while vegetation on the beach included Calophyllum inophyllum and Terminalia catappa, whereas the dominant species were Ipomoea pes-caprae, and Sesuvium portulacastrum. Meanwhile, the dominant species of mangrove were Avicennia marina, Rhizophora mucronata, Excoecaria agallocha, and Bruguiera gymnorrhiza.

Table 1. List of species recorded in Ciletuh Geopark, West Java, Indonesia

\begin{tabular}{|c|c|}
\hline Family & Species \\
\hline Acanthaceae & Acanthus ilicifolius $\mathrm{L}$. \\
\hline Aizoaceae & Sessuvium portulacastrum (L.) L. \\
\hline Amaryllidaceae & Crinum asiaticum $\mathrm{L}$. \\
\hline Anacardiaceae & Anacardium occidentale $\mathrm{L}$. \\
\hline Anacardiaceae & Dracontomelon mangiferum Blume \\
\hline Anacardiaceae & Gluta renghas $\mathrm{L}$. \\
\hline Anacardiaceae & Gluta wallichii (Hook.f.) Ding Hou \\
\hline Anacardiaceae & Mangifera foetida Blume \\
\hline Anacardiaceae & Mangifera indica $\mathrm{L}$. \\
\hline Anacardiaceae & Spondias dulcis Forst.f. \\
\hline Annonaceae & Orophea hexandra Blume \\
\hline Apocynaceae & Alstonia scholaris (L.) R. Br. \\
\hline Araceae & Alocasia longifolia Engl. \& K. Krause \\
\hline Araceae & Colocasia esculenta Schott \\
\hline Arecaceae & Aegle marmelos (L.) Corrêa \\
\hline Arecaceae & Arenga obtusifolia Mart. \\
\hline Arecaceae & Arenga pinnata (Wurmb) Merr. \\
\hline Arecaceae & Calamus viminalis Willd \\
\hline Arecaceae & Caryota rumphiana Mart. \\
\hline Arecaceae & Cocos nucifera Linn. \\
\hline Arecaceae & Daemonorops melanochaetes Blume \\
\hline Arecaceae & Pinanga coronata (Blume ex Martelli) Blume \\
\hline Arecaceae & Plectocomia elongata $\mathrm{L}$. \\
\hline Asparagaceae & Cordyline fruticosa (L.) A.Chev. \\
\hline Aspleniaceae & Asplenium nidus L. \\
\hline Asteraceae & Ageratum conyzoides $(\mathrm{L}.) \mathrm{L}$. \\
\hline Asteraceae & Chromolaena odorata (L.) R.M.King \& H.Rob. \\
\hline Asteraceae & Crassocephalum crepidiodes (Benth.) S. Moore \\
\hline Asteraceae & Erigeron sumatrensis Retz. \\
\hline Asteraceae & Mickania cordata (Burm.f.) B.L.Rob. \\
\hline Asteraceae & Sonchus arvensis L. \\
\hline Asteraceae & Wedelia triloba (L.) Hitchc. \\
\hline Averrhoaceae & Averrhoa bilimbi $\mathrm{L}$. \\
\hline Avicenniaceae & Avicennia marina (Forssk.) Vierh. \\
\hline Balsaminaceae & Impatiens platypetala \\
\hline Bambusaceae & Bambusa vulgaris Schrad. \\
\hline Bambusaceae & Dendrocalamus asper (Schult.) Backer \\
\hline Bambusaceae & Gigantochloa apus (Schult.) Kurz \\
\hline Bambusaceae & Gigantochloa atroviolacea Widjaja \\
\hline Bambusaceae & Gigantochloa atter (Hassk.) Kurz \\
\hline Bambusaceae & Thyrsostachys siamensis Gamble \\
\hline
\end{tabular}

\begin{tabular}{|c|c|}
\hline Begoniaceae & Begonia robusta Blume \\
\hline Bignoniaceae & Oroxylum indicum (L.) Kurz \\
\hline Bombacaceae & Durio zibethinus Murr \\
\hline Caricaceae & Carica papaya $\mathrm{L}$. \\
\hline Clusiaceae & Calophyllum inophyllum $\mathrm{L}$. \\
\hline Combretaceae & Terminalia catappa $\mathrm{L}$. \\
\hline Convolvulaceae & Ipomoea pes-caprae (L.) R. Br. \\
\hline Cycadaceae & Cycas rumphii Miq. \\
\hline Dilleniaceae & Dillenia indica $\mathrm{L}$. \\
\hline Dilleniaceae & Tetracera scandens (L.) Merr. \\
\hline Dioscoreaceae & Dioscorea hispida Dennst. \\
\hline Ebenaceae & Diospyros pilosanthera Blanco \\
\hline Euphorbiaceae & Acalypha lanceolata Willd. \\
\hline Euphorbiaceae & Euphorbia hirta L. \\
\hline Euphorbiaceae & Excoecaria agallocha $\mathrm{L}$. \\
\hline Euphorbiaceae & Macaranga gigantea Rchb.f. \& Zoll.) Müll.Arg. \\
\hline Euphorbiaceae & Manihot esculenta Crantz \\
\hline Fabaceae & Acacia auriculiformis Benth. \\
\hline Fabaceae & Acacia mangium Willd. \\
\hline Fabaceae & Albizia lebbeck (Osbeck). Merr. \\
\hline Fabaceae & Albizia procera (Roxb.) Benth. \\
\hline Fabaceae & Albizzia lebbeck L. \\
\hline Fabaceae & Archidendron pauciflorum (Benth.) I.C.Nielsen \\
\hline Fabaceae & Calliandra calothyrsus Meisn \\
\hline Fabaceae & Callotropis gigantea (Hook.) G.Don \\
\hline Fabaceae & Cynometra ramiflora $\mathrm{L}$. \\
\hline Fabaceae & Erythrina variegata $\mathrm{L}$. \\
\hline Fabaceae & Gliricidia sepium (Jacq.) Walp. \\
\hline Fabaceae & Gliricidia sepium $\mathrm{L}$. \\
\hline Fabaceae & Milletia elliptica (Roxb.) Steud. \\
\hline Fabaceae & Mimosa pigra $\mathrm{L}$. \\
\hline Fabaceae & Mimosa pudica $\mathrm{L}$. \\
\hline Fabaceae & Parkia speciosa Hassk. \\
\hline Fabaceae & Parkia speciosa Hassk. \\
\hline Fabaceae & Pueraria phaseoloides (Roxb.) Benth. \\
\hline Fabaceae & Senna siamea (Lam.) H.S.Irwin \& Barneby \\
\hline Fabaceae & Tamarindus indica $\mathrm{L}$. \\
\hline Goodeniaceae & Scaevola taccada (Gaertn.) Roxb. \\
\hline Hypoxidaceae & Molineria capitulata (Lour.) Herb. \\
\hline Lamiaceae & Clerodendrum laevifolium Blume \\
\hline Lamiaceae & Tectona grandis Linn.f. \\
\hline Lythraceae & Lagerstroemia speciosa (L.) Pers. \\
\hline Malvaceae & Ceiba petandra Gaertn. \\
\hline Malvaceae & Grewia laevigata Vahl. \\
\hline Malvaceae & Heritiera sp. \\
\hline Malvaceae & Hibiscus rosa-sinensis $\mathrm{L}$. \\
\hline Malvaceae & Hibiscus tiliaceus $\mathrm{L}$. \\
\hline Malvaceae & Melochia umbellata (Houtt.) Stapf \\
\hline Malvaceae & Pterocymbium tinctorium Merr. \\
\hline Malvaceae & Pterospermum javanicum Jungh. \\
\hline Malvaceae & Thespesia populnea (L.) Sol. ex Corrêa \\
\hline Melastomataceae & Clidemia hirta (L.) D. Don \\
\hline Melastomataceae & Melastoma malabatrihcum Jack. \\
\hline Meliaceae & Aglaia teysmanniana (Miq.) Miq. \\
\hline Meliaceae & Dysoxylum alliaceum (Blume) Blume \\
\hline Meliaceae & Dysoxylum caulostachium (Blume) Blume \\
\hline Meliaceae & Lansium parasiticum (Osbeck) K.C.Sahni \& Bennet \\
\hline Meliaceae & Swietenia macrophylla King \\
\hline Meliaceae & Swietenia mahagoni (L.) Jacq. \\
\hline Meliaceae & Toona sinensis $\mathrm{R}$. Roem \\
\hline Moraceae & Artocarpus altilis (Parkinson) Fosberg \\
\hline Moraceae & Artocarpus elastica Roxb. \\
\hline Moraceae & Ficus ampelas .Burm.f. \\
\hline Moraceae & Ficus ampelas Burm.f. \\
\hline Moraceae & Ficus benjamina $\mathrm{L}$. \\
\hline Moraceae & Ficus fistulosa Reinw. ex Blume \\
\hline Moraceae & Ficus grossularioides Burm.f. \\
\hline
\end{tabular}




\begin{tabular}{|c|c|}
\hline Moraceae & Ficus lepicarpa Blume \\
\hline Moraceae & Ficus rostrata Thunb. \\
\hline Moraceae & Ficus septica Burm.f. \\
\hline Moraceae & Ficus sumatrana Miq. \\
\hline Moraceae & Ficus variegata Blume \\
\hline Moraceae & Parartocarpus venenosa Becc. \\
\hline Moraceae & $\begin{array}{l}\text { Stelechocarpus burahol (Blume) Hook.f. \& } \\
\text { Thomson }\end{array}$ \\
\hline Muntingiaceae & Muntingia calabura $\mathrm{L}$. \\
\hline Musaceae & Musa acuminata Colla. \\
\hline Musaceae & Musa x paradisiaca $\mathrm{L}$. \\
\hline Myrtaceae & Psidium guajava L. \\
\hline Myrtaceae & Syzygium aromaticum (L.) Merr. \& L.M.Perry \\
\hline Myrtaceae & Syzygium densiflorum Wall. ex Wight \& Arn. \\
\hline Myrtaceae & Syzygium jambos (L.) Alston \\
\hline Myrtaceae & Syzygium lineatum (DC.) Merr. \& L.M.Perry \\
\hline Pandanaceae & Galearia filiformis Boerl. \\
\hline Pandanaceae & Pandanus furcatus Roxb. \\
\hline Pandanaceae & Pandanus tectorius Parkinson ex Du Roi \\
\hline Passifloraceae & Passiflora foetida $\mathrm{L}$. \\
\hline Phyllanthaceae & Breynia racemosa (Blume) Müll.Arg. \\
\hline Phyllanthaceae & Cleistanthus monoicus (Lour.) Müll.Arg. \\
\hline Phyllanthaceae & Phyllanthus emblica L. \\
\hline Piperaceae & Piper aduncum $\mathrm{L}$. \\
\hline Piperaceae & Piper betle L. \\
\hline Poaceae & Spinifex littoreus (Burm. f.) Merr. \\
\hline Poaceae & $\begin{array}{l}\text { Brachiaria reptans (L.) C.A.Gardner \& } \\
\text { C.E.Hubb. }\end{array}$ \\
\hline Poaceae & Cymbopogon citratus (DC.) Stapf \\
\hline Poaceae & Imperata cylindrica (L.) Raeusch. \\
\hline Poaceae & Oryza sativa $\mathrm{L}$. \\
\hline Poaceae & Oryza sativa var. $\mathrm{x}$ \\
\hline Poaceae & Panicum maximum Jacq. \\
\hline Poaceae & Pennisetum polystachion (L.) Schult. \\
\hline Poaceae & Saccharum spontaneum $\mathrm{L}$. \\
\hline Poaceae & Zea mays L. \\
\hline Polygalaceae & Xanthophyllum excelsum (Blume) Miq. \\
\hline Rafflesiaceae & Rafflesia patma Blume. \\
\hline Rhizophoraceae & Bruguiera cylindrica (L.) Blume \\
\hline Rhizophoraceae & Bruguiera gymnorrhiza (L.) Lamk \\
\hline Rhizophoraceae & Carallia brachiata (Lour.) Merr. \\
\hline Rhizophoraceae & Rhizophora mucronata Lam. \\
\hline Rubiaceae & Guettarda speciosa $\mathrm{L}$. \\
\hline Rubiaceae & Morinda citrifolia $\mathrm{L}$. \\
\hline Rubiaceae & Neolamarckia cadamba (Roxb.) Bosser \\
\hline Rubiaceae & Neonauclea lanceolata (Blume) Merr. \\
\hline Rutaceae & Acronychia pedunculata (L.) Miq. \\
\hline Rutaceae & Citrus aurantiifolia (Christm.) Swingle \\
\hline Rutaceae & Citrus hystrix DC. \\
\hline Rutaceae & Melicope latifolia (DC.) T.G. Hartley \\
\hline Sapindaceae & Filicium decipiens (Wight \& Arn.) Thwaites \\
\hline Sapotaceae & Chrysophyllum cainito $\mathrm{L}$. \\
\hline Sapotaceae & Manilkara zapota (L.) P.Royen \\
\hline Sapotaceae & Palaquium rostratum (Miq.) Burck \\
\hline Sterculiaceae & Sterculia foetida $\mathrm{L}$. \\
\hline Tetramelaceae & Tetrameles nudiflora $\mathrm{R} . \mathrm{Br}$. \\
\hline Urticaceae & Oreocnide rubescens Blume \\
\hline Verbenaceae & Lantana camara $\mathrm{L}$. \\
\hline Verbenaceae & Stachytarpheta jamaicensis Gardn \\
\hline Zingiberaceae & Alpinia galanga (L.) Willd. \\
\hline Zingiberaceae & Costus speciosus (J.Konig) Sm. \\
\hline Zingiberaceae & Curcuma longa $\mathrm{L}$. \\
\hline Zingiberaceae & Etlingera megalocheilos (Griff.) A.D.Poulsen \\
\hline Zingiberaceae & Hedychium roxburghii Blume \\
\hline Zingiberaceae & Zingiber officinale Roscoe \\
\hline
\end{tabular}

\section{Discussion}

In Ciletuh Geopark there has been changes in land use in which agricultural land was more dominant than forest. The existing forest vegetation was only remained in few areas, meaning that previously Ciletuh Geopark had experienced deforestation. Deforestation is the conversion of forest areas to non-forest land use (Gervet, 2007). Agriculture is one of the most significant causes of deforestation (Bennett, 2017). Effect deforestation includes the reduction or even loss of native species replaced by cultivated species. Deforestation can be caused by several factors including population pressures, commercial activities, and social and political conditions.

Currently, Ciletuh Geopark is dominated by talun/ kebon tatangkalan. Talun is an agroforestry system formed to increase overall productivity and serve various functions by combining agricultural crops with tree vegetation (Berkes 2012; Parikesit et al. 2005). Kebon tatangkalan has distinctive features and has developed under the influence of various biophysical and socio-economic factors (Parikesit et al. 2005).

Soerianegara and Indrawan (2005) state natural plant communities in tropical forests have at least three strata. Although the Ciletuh Geopark was dominated by trees from strata B and C, but the forest in the Puncak Manik area was still dominated by trees from strata A. Vegetation in Ciletuh Geopark were arranged of trees from strata A, B, and $\mathrm{C}$, indicating the existence of old plants (Suci et al. 2017). The findings of this study highlight the importance of conserving the remaining natural vegetation in Ciletuh Geopark to enhance the biological values of the geopark.

\section{ACKNOWLEDGEMENTS}

This study was funded ALG through Prof. Erri N. Megantara. We thank Institute Ecology Team who assisted research preparation, data collection, and analysis, as well as the PAPSI and the Ciletuh community for all assistance during data collection. We also thank Prof. Tri Hanggono Achmad, the rector of the Padjadjaran University, who supported the ALG program and encouragement to conduct research.

\section{REFERENCES}

Bennett L. 2017. Deforestation and Climate Change. Climate Institute. Washington DC.

Berkes F. 2012. Sacred Ecology. Routledge. New York.

Gem C. 1996. Kamus Saku Biologi. Erlangga. Jakarta.

Gervet B. 2007. Deforestation Contributes to Global Warming. Luleå University of Technology. Luleå, Sweden.

Megantara EN. 2016. Biodiversity Ciletuh: Sekilas Diversitas Hayati \& Sebaran REEPS (Rare, Endangered, Endemic, \& Protected Species). Unpad Press. Bandung. [Indonesian]

Misra R. 1973. Ecology Work Book. Oxford and IBH Publishing Co. New Delhi.

Mueller-Dombois D, Ellenberg H. 1974. Aims and Methods of Vegetation Ecology. John Wiley \& Sons, New York.

Parikesit, Takeuchi K, Tsunekawa A, Abdoellah OS. 2004. Kebon Tatangkalan: A disappearing agroforest in the Upper Citarum Watershed, West Java, Indonesia. Agrofor Syst 63 (2): 171-182. DOI: $10.1007 / \mathrm{s} 10457-004-1182-\mathrm{x}$ 
Richard PW. 1966. The Tropical Rain Forest an Ecological Study. Cambridge University Press, London.

Soerianegara I, Indrawan A. 2005. Ekologi Hutan Tropika. Bogor Laboratorium Ekologi Hutan Fakultas Kehutanan Institut Pertanian Bogor. Bogor.
Suci, Dahlan Z, Yustian I2017. Propil vegetasi di kawasan hutan konservasi Suaka Margasatwa Gunung Raya Kecamatan Warkuk. Jurnal Penelitian Sains 19 (1): 47-53. [Indonesian] 